\title{
THE EFFECTIVENESS OF USING MEMRISE APPLICATION IN TEACHING VOCABULARY
}

\author{
Ai Siti Nuralisah ${ }^{1}$, Evie Kareviati ${ }^{2}$ \\ ${ }^{1}$ IKIP Siliwangi \\ ${ }^{2}$ IKIP Siliwangi \\ ${ }^{1}$ aisitinuralisah6@gmail.com, ${ }^{2}$ ekareviati@gmail.com
}

\begin{abstract}
This research is based on the use of the Memrise application in a vocabulary study of seventh-grade students. This research was carried out based on a preliminary study which showed that students had difficulty learning English because of the lack of understanding of the vocabulary they had, and the method used by the teacher to teach vocabulary is still in a conventional way. The subjects of this study were 35 students consisting of 28 male and 10 female seventh-grade students of SMPN 1 Cililin. The purpose of this study is to improve students' understanding and achievement of vocabulary through the use of the Memrise application. Vocabulary tests and questionnaires were used as the instruments of eliciting the data. The results of the test and questionnaire study showed an increase in grades, and students' interest and motivation after using the memrise application in vocabulary learning. From the results obtained, it was concluded that memrise application is recommended to be used as an alternative method in teaching vocabulary. Besides students, with this Memrise application, it can add to the teacher's insight about the use of methods in teaching in the classroom.
\end{abstract}

Keywords: Teaching, Vocabulary, Memrise Application

\section{INTRODUCTION}

Language is one of the important abilities that humans must possess. One of every language skills needed to find out is English. Acquisition is incredibly necessary to form it easier to know English learning for review (Ramírez \& Kuhl, 2020). Language is also closely related to learning because learning strategies are the main key in learning languages and conversely language is the key to the learning process (Mehrabian, Salehi, \& Branch, 2019). In understanding English learning, one in each of the essential skills that have to be possessed is vocabulary. Vocabulary is generically defined as the knowledge of words and word meanings. More specifically, we use vocabulary to refer to the kind of words that students must know to read increasingly demanding text with comprehension (Hiebert, 2005) as cited in Nurdiansyah, Asyid, \& Parmawati (2019).

According to Nugroho (2012 cited in Farida, Isrina \& Apsari, 2019), Vocabulary is the foundation to develop languages, which has a role as a basis in communication. Thus, vocabulary is basic and important learning that must be learned in language learning (Sari \& Sutopo, 2018). In other words, vocabulary mastery plays an important role in the whole process of learning a second language (Giessen, 2019). By learning vocabulary, it will be easier to know four skills in English, specifically speaking, reading, writing, and speaking (Indrasari, Novita, \& Megawati, 2018). Communication of scholars in learning, channeling concepts, opinions and information are easier if students have studied the vocabulary well (Aisyah, Hidayatur Rahma, \& Yugafiati, 2019) 
There are some problems in the teaching-learning process, especially in vocabulary learning. obstacles experienced by students include a low understanding of English, a lack of motivation to learn vocabulary, and difficulty in translating English sentences. In addition, teachers who teach still use conventional methods, where the teacher only provides English texts, and students are asked to translate using a dictionary. This way bores students and spends a long time understanding the given sentence.

Based on all the problems above, researchers conducted a study of learning actions using the application Memrise to solve existing problems in learning English vocabulary. The purpose of this study is to improve student achievement and interest in the vocabulary learning of seventhgrade students at school.

To increase students' motivation and interest in learning vocabulary, the teacher should produce learning methods and strategies that are preferred by students. The strategy taken is very important to make the process of learning and learning in class more fun. One strategy which will be used is to use the Memrise application. Memrise is one tool to help teachers and students teach and understand language learning easily through mobile devices. Memrise is also an appropriate application for vocabulary learning. Using this application in class is an effective way to increase the interest of students who are learning vocabulary.

\section{Vocabulary}

There some aspects of vocabulary that should be mastered by students as proposed by Ur (Yugafiati \& Priscila, n.d.)They are as follows:

a. Pronunciation and orthography The Students must understand the pronunciation and spelling of a word.

b. Grammar The grammatical rules ought to be understood by student after they learn a group of latest words.

c. Meaning

The Students must know the meaning of words that are there to make it easier to remember the vocabulary that is being studied.

\section{Technique of teaching vocabulary}

In vocabulary learning, there are three stages (Lelawati, Dhiya, \& Mailani, 2018):

a. Technique presenting

The stage required for students to be introduced to new words. As an English teacher, we must always understand vocabulary teaching techniques that are appropriate for students

b. Technique in active

In active stage, there square measure a spread of tasks which might be utilized in order to assist move words into memory.

c. Media may be a main instrument in teaching and learning method.

This usually attracts the attention of students and conveys data simply. Teachers must be forced to use some visuals in their teaching activities to facilitate their teaching. For example, there are various media sizes, but visuals are suitable for students in learning vocabulary. 


\section{Memrise Application}

Memrise is an internet learning tool that specializes in vocabulary development and was founded by Ed Cooke, Grand Master of Memory, and Greg Detre, a Princeton neuroscientist who specializes in memory science and forgetting.

This tool contains a very specific audience who wants to find out about vocabulary development. Therefore, every teacher who wants to encourage their students to find out their vocabulary data or every student who aims to improve their vocabulary simply and with a very pleasant method is expected from the audience of this tool. Memrise is very easy to use. To increase the speed of learning and remembering memrise using a flash card repetition (Aminatun \& Oktaviani, 2019)

This application can be used with a website, and sign in using a Google or Facebook account, but can also be done by downloading the application in the play store or mobile app store so that it can be used more easily and practically.

\section{METHOD}

This study employs descriptive-qualitative design. According to (Lelawati et al., 2018) qualitative research uses researchers as the main source and source of direct data. The purpose of this study is to study the effective level of students' vocabulary skills in the classroom by using the application memrise. The researcher explains the effectiveness of the application memrise to teaching vocabulary. The treatment which was used in this research was using Memrise Application. The subject was 35 students who consist of 20 females, and 15 male students at seven grades of one of the junior high schools in SMPN 1 Cililin.

In this study, the researcher collected data through pretest and posttest according to (Farida, Dian Isrina, \& Apsari, 2019), interviews by asking open-ended questions and using a questionnairethat encouraged respondents to express their feelings, attitudes, and perceptions. (Gunawan \& Saputra, 2020) a questionnaire is a written instrument that presents a series of questions or statements that must be responded to by writing down the answers. The purpose of all these instruments is to analyze the teacher's strategy in teaching English vocabulary and students' responses to the implementation of teaching English vocabulary.

\section{RESULTS AND DISCUSSION}

\section{Results}

From the interview, the researcher found that the main problem was the lack of student motivation to learn English. Some students did not bring english dictionary and did not give attention to the teacher when explaining the material. They talk about difficulties in translating English words, and teacher strategies in teaching are less varied. Teachers need new teaching strategies to improv student's motivation and achievement in English.

In this study, researchers used the Memrise application. There were 3 meetings conducted by researchers. First, the pretest is done to see the ability of students to be introduced with Memrise application, the second treatment is to apply the vocabulary teaching application using the Memrise application, and finally, the posttest, to see students' improvement and differences.

The results of the post-test and pre-test are shown in the table 
Table 1. Student's score post-test and pre-test

\section{Student's score}

\begin{tabular}{|c|c|c|c|}
\hline & nt's name & Pre-test & Post-test \\
\hline 1 & ARM & 78 & 84 \\
\hline 2 & $\mathrm{AP}$ & 80 & 96 \\
\hline 3 & AS & 78 & 90 \\
\hline 4 & AMM & 84 & 96 \\
\hline 5 & DWS & 80 & 96 \\
\hline 6 & DN & 74 & 86 \\
\hline 7 & DT & 78 & 96 \\
\hline 8 & FDAY & 78 & 90 \\
\hline 9 & FA & 70 & 88 \\
\hline 10 & FKZ & 80 & 92 \\
\hline 11 & FB & 66 & 78 \\
\hline 12 & HA & 68 & 78 \\
\hline 13 & KSH & 68 & 80 \\
\hline 14 & KKA & 72 & 84 \\
\hline 15 & LNF & 70 & 84 \\
\hline 16 & MRK & 64 & 78 \\
\hline 17 & MRA & 78 & 86 \\
\hline 18 & MF & 74 & 88 \\
\hline 19 & MFD & 80 & 92 \\
\hline 20 & MRP & 70 & 84 \\
\hline 21 & NA & 56 & 78 \\
\hline 22 & NSF & 62 & 80 \\
\hline 23 & NDN & 60 & 82 \\
\hline 24 & $\mathrm{NP}$ & 46 & 78 \\
\hline 25 & PGP & 49 & 80 \\
\hline 26 & $\mathrm{PF}$ & 78 & 90 \\
\hline 27 & RIH & 56 & 78 \\
\hline 28 & RSP & 80 & 96 \\
\hline 29 & RN & 70 & 90 \\
\hline 30 & $\mathrm{RH}$ & 68 & 84 \\
\hline 31 & SEG & 56 & 88 \\
\hline 32 & SGN & 62 & 76 \\
\hline 33 & SAP & 60 & 78 \\
\hline 34 & WAH & 50 & 76 \\
\hline \multirow[t]{3}{*}{35} & YSN & 48 & 76 \\
\hline & Total & 2391 & 2976 \\
\hline & Average & 68,3 & 85,1 \\
\hline
\end{tabular}

The above results show that the average pre-test score of students is 68,3 and on the post-test is 85,1 . The results showed that there was an increase in student scores in the post-test

The results of the test showed the score of students in the pre-test was below the passing score. Hope, the first success criteria haven't been agreed upon. Before the study was conducted the 
researchers found that in previous meetings students were not given special care to provide vocabulary and in a short time, students tended to be bored and not interested in more vocabulary.

From this information, researchers conducted learning using the Memrise application at the second meeting. In this meeting, making vocabulary learning more fun than before. After the researchers conducted the study, a post-test was conducted to determine the increase in students' abilities.

The post-test results showed the average student scored 85, 2. Student scores increased and all students were able to achieve passing scores,

The second success criterion is students are motivated to join an English class. To achieve the second success criterion, researchers used observations and questionnaires. From observations, the researchers found that after treatment using the Memrise application to teach vocabulary, students were happy and excited about learning. After post-test, students are given a questionnaire, to see students' responses to learning methods using the Memrise application. The result of the questionnaire can bee seen on table 2 .

Table 2. Student's questionnaire results

\begin{tabular}{lcc}
\hline \multirow{2}{*}{ Quistions } & \multicolumn{2}{c}{ Student's Answer } \\
\cline { 2 - 3 } & Yes & No \\
\hline Do you like Memrise app that is applied by your English teacher? & 35 & 0 \\
Does that app make you happy in joining the English class? & 30 & 5 \\
Does that app make you enjoy the teaching learning process? & 30 & 5 \\
Do you think that app motivate you in learning English? & 34 & 1 \\
Does that app help you to memorize English vocabulary? & 28 & 7 \\
Does that application help you to understand English easier & 25 & 15 \\
\hline
\end{tabular}

The questionnaire showed that most students were more interested when teachers applied the memrise application to learn English vocabulary. Students think that memrise applications can help and make it easier for students to memorize English words. From the above table, it can be concluded that the second success criterion is achieved.

\section{Discussion}

From this research, it can be seen that vocabulary learning using memrise application is effective for improving students' language skills. This application can be used two times in one study. In the first session, the students were shown vocabulary and their meanings, and students began to memorize the words indicated, then in the second session, the students were given a quiz to relate the words they had memorized before.

In implementing this application, the teacher must consider the topic. The more interesting the topic discussed the more it makes students interested in what they are learning.

The advantage of using this application is to make students motivated and happier in learning English and make it easier for students to memorize words. This can also increase the sense of cooperation with each other. Besides this application can be used in various languages, not only 
English. Discussion should be an interpretation of the results rather than a repetition of the Results.

\section{CONCLUSION}

The research findings show that research using Memrise is effective for increasing students' vocabulary mastery. Students memorize vocabulary more easily and are happy in the learning process. This application is also one of the reference learning strategies that teachers can do to teach in class. For readers of this research can also add and develop English language material that is owned.

\section{ACKNOWLEDGMENTS}

All praises be to Allah. Which has provided opportunities and strength and health to be able to learn and complete this article.

This article was written to fulfill one of the final exam requirements at IKIP Siliwangi. The researchers also would like to thank all lectures in siliwangi who guide and motivate to finish this article, especially to Miss Dra. Evie Kareviati, M.Pd as my guide. Do not forget also for parents, and friends who support researchers.

Hopefully this research will be useful for readers or other researchers in the future.

\section{REFERENCES}

Aisyah, N. S., Hidayatur Rahma, N. A., \& Yugafiati, R. (2019). Improving Student's Vocabulary Mastery Through Cooperative Script On Descriptive Text. Project (Professional Journal Of English Education), 2(2), 181.

Aminatun, D., \& Oktaviani, L. (2019). Memrise: Promoting Students' Autonomous Learning Skill Through Language Learning Application. Metathesis: Journal Of English Language, Literature, And Teaching, 3(2), 214.

Farida, D., Isrina, H. D., \& Apsari, Y. (2019). The Implementation Of Flash Cards To Improve Students'vocabulary Mastery. Project (Professional Journal Of English Education), 2(3), 352-357.

Giessen, H. (2019). An Explorative Study On Media Effects In Vocabulary Learning. Lublin Studies In Modern Languages And Literature, 43(4), 147.

Gunawan, S., \& Saputra, H. (2020). Problems And Teaching Solutions For Students' In Learning English. Project (Professional Journal Of English Education), 3(1), 59.

Indrasari, A., Novita, D., \& Megawati, F. (2018). Big Book: Attractive Media For Teaching Vocabulary To Lower Class Of Young Learners. Jees (Journal Of English Educators Society), 3(2), 141.

Lelawati, S., Dhiya, S., \& Mailani, P. N. (2018). The Teaching Of English Vocabulary To Young Learners. Project (Professional Journal Of English Education), 1(2), 95-100.

Mehrabian, N., Salehi, H., \& Branch, N. (2019). The Effects Of Using Diverse Vocabulary Learning Strategies On Word Mastery: A Review. Journal Of Applied Studies In Language, 3(1), 100-114.

Nurdiansyah, D. M. R., Asyid, S. A., \& Parmawati, A. (2019). Using Color Coding To Improve Students'english Vocabulary Ability. Project (Professional Journal Of English Education), 2(3), 358-363.

Ramírez, N. F., \& Kuhl, P. K. (2020). Early Second Language Learning Through Sparkling ${ }^{\mathrm{tm}}$ : Scaling Up A Language Intervention In Infant Education Centers. Mind, Brain, And Education. 
Sari, L. I., \& Sutopo, D. (2018). The Effectiveness Of Vocabulary Self-Collection And Word Mapping Strategies For Teaching Vocabulary To Maritime Cadets With High And Low Metacognitive Awareness. English Education Journal, 8(1), 35-42.

Yugafiati, R., \& Priscila, T. (N.D.). The Use Of Mind Map To Improve Students 'Vo Cabulary. 98-105. 